\author{
Свистун Т.В. \\ кандидат економічних наук, доцент \\ E-mail: tatyana dud@mail.ru \\ Туз К.B. \\ магістрант \\ кафредра управління бізнесом \\ Одеська національна академія харчових технологій \\ вул. Канатна, 112, м. Одеса, Україна, 65039 \\ E-mail: Katia-tuz@yandex.ru
}

\title{
АНАЛІЗ РИНКУ ЗАМОРОЖЕНИХ НАПІВФАБРИКАТІВ УКРАЇНИ
}

В статті розглянуто основні тенденції споживання і асортимент зморожених напівфрабрикатів Україні. Під час проведення аналізу були визначені: лідери ринку України, основні проблеми виробників, чинники, що впливають на розвиток.

Ключові слова: заморозка, напівфабрикати, лідери ринку, основні виробники, розвиток галузі.

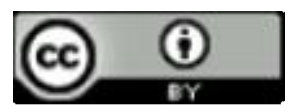

This work is licensed under a Creative Commons Attribution 4.0 International License http://creativecommons.org/licenses/by/4.0/

Постановка проблеми та її зв'язок з важливими науковими та практичними завданнями. Сучасні тенденції у харчуванні населення все більше орієнтовані на розвиток ринку швидких і легких у приготуванні продуктів, які одночасно мають високу харчову цінність і доступні для пересічного споживача.В сучасному ритмі житті напівфабрикат - це дуже популярний продукт серед домогосподарок в силу того, що готується він досить швидко і легко. Подібні продукти є майже готовими. Найчастіше їх навіть не потрібно розморожувати перед тим, як готувати. Напівфабрикат необхідно тільки обсмажити, зварити або ж всього-на-всього підігріти в мікрохвильовій печі. Після чого виріб вже готовий до вживання і його можна подавати до столу.

Аналіз останніх публікацій 3 проблеми. Дослідженню напрямку розвитку напівфабрикатної галузі України присвячені роботи: О. Соколов, С. Михайльчук, Шубіна Г. [5], Шугурова Т.[6] та інших дослідників.

Формулювання цілей дослідження. Дане дослідження полягає у вивчені ринку заморожених напівфабрикатів і вивчення лідерів ринку.

Виклад основних результатів та їх обгрунтування. Зараз світовий ринок заморожених продуктів харчування оцінюється в \$ 40 млрд. на рік і неухильно розвивається. У США, наприклад, 94\% жителів споживають заморожені напівфабрикати. Тенденція останнього часу - виробництво все більш складних продуктів вищої цінової категорії [2].

У «заморозки» $є$ виробнича особливість, що створює відміну від інших сфер харчової промисловості. Так промисловий спосіб заморожування у великих обсягах вважається найбільш ефективним, оскільки забезпечує моментальну, шокову заморозку при дуже низькій температурі, а значить, є найбільш щадним способом, який зберігає максимум корисних речовин продукту.

Продукція заморожених напівфабрикатів включає в себе. пельмені, м'ясні напівфабрикати, млинці, піцу, вареники, заморожені вироби 3 тіста i готові страви [4].

Найпопулярніша категорія напівфабрикатів в Україні - м'ясні напівфабрикати(з використанням тіста і без нього). Разом з пельменями їх частка становить понад $80 \%$ від усього споживання заморожених напівфабрикатів. Серед м'ясних напівфабрикатів можна виділити рубані напівфабрикати (фарш, різні котлети, биточки, зрази, фрикадельки). Спостерігається зростання попиту на м'ясні напівфабрикати 3 птиці. оскільки дана продукція вважається більш дієтичною. У Європі ж найбільш популярним напівфабрикатів є піца. Найменшу частку займають нем'ясні варіанти продукції: вареники з картоплею, грибами, капустою, сиром і т.п. Останнім часом спостерігається незначне зростання сегмента заморожених хлібобулочних виробів, рибних напівфабрикатів, заморожених плодів і овочів, листкового тіста [1].

Ринок заморожених готових напівфабрикатів в Україні стикається 3 низкою складнощів, які в цілому призводять до скорочення обсягів виробництва, споживання і відсутності позитивної динаміки розвитку ринку. Основними проблемами, з якими стикаються виробники - це: відсутність якісного і недорогої сировини внутрішнього виробництва, і проблеми збуту продукції через жорсткої політики торговельних мереж.

Крім того в останні роки в засобах мас-медіа не раз підіймалося питання про шкоду готової напівфабрикатної м'ясної продукції, що сприяло падінню попиту на напівфабрикати. Відсутність на ринку серйозних зарубіжних виробників і недостатні потужно- 
сті національних гравців тільки сприяють тому, що в Україні не проводиться активна маркетингова політика, яка захищала б і просувала продукцію заморожених напівфабрикатів.

Динаміка ринку напівфабрикатів заморожених залежить від доходів населення. Найбільшу частку займає продукція середньо- і низькоцінового сегмента. Зі збільшенням рівня доходів населення збільшується і попит на продукцію високоціновому сегмента, однак, в Україні частка продукції преміум-сегмента всього близько 3\%. У преміум-сегменті представлена брендована продукція, виготовлена 3 натуральної сировини, але така продукція занадто дорога для споживачів з низьким і середнім рівнем доходу [7].

Останнім часом розвиток ринку заморожених напівфабрикатів не можна назвати активним, оскільки значного зростання в споживанні або попиті на дану продукцію не спостерігається. Саме тому багато вітчизняних виробників прагнуть мінімізувати свої витрати на маркетингове просування і намагаються зберегти свої ринкові позиції за рахунок введення на ринок нових продуктів і за рахунок експортної діяльності в країни СНД.
Структура ринку заморожених продуктів в Україні істотно відрізняється від західної. У європейських країнах переважають сегменти овочів і ягід, а у нас - продукти, характерні для національної кулінарної традиції, зокрема пельмені і вареники.

Лідерство цього народного продукту склалося історично, і в недалекому майбутньому ситуація навряд чи кардинально зміниться, адже пельмені регулярно купують майже три чверті українських споживачів [6].

Що стосується структури ринку, то питома вага пельменів на ньому складає більше половини загального продажу - близько $63 \%$, вареників - близько $16 \%$, котлет - 6\%, фаршу - 4\%, рибних паличок, бургерів - 3\%, заморожених хлібобулочних виробів -2 $\%$, піци - 2\%. Найбільший обсяг споживання продуктів глибокої заморозки припадає на нижній і середній ціновий сегменти [3].

Поточні результати голосування Інтернетаудиторії 2016 року показали, що найбільш популярні є торові марки «Три ведмеді», «Геркулес» і «Левада» $[8]$.

Таблиця 1

\section{Результати голосування Інтернет-аудиторії за 2015 та 2016роки щодо вибору торговельної марки напівфабрикатів [8]}

\begin{tabular}{|c|c|c|}
\hline 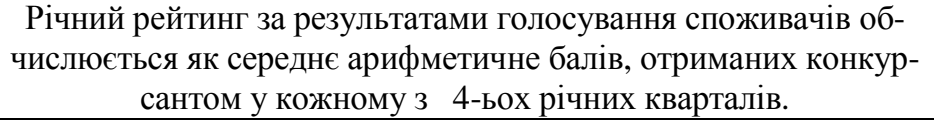 & 2015 рік & $\begin{array}{c}2016 \text { рік } \\
\text { (за } 3 \text { квартали) }\end{array}$ \\
\hline Три Ведмеді & 39,38 & $40,19 \%$ \\
\hline Геркулес & 43,78 & $39,25 \%$ \\
\hline Левада & 35,49 & $25,7 \%$ \\
\hline VICI (Вичюнай Україна) & 21,24 & $18,69 \%$ \\
\hline Ятрань (М’ясокомбінат «Ятрань») & 20,47 & $16,82 \%$ \\
\hline Лімо (Львівський холодокомбінат) & 8,03 & $12,15 \%$ \\
\hline Ермолино & 9,59 & $13,55 \%$ \\
\hline Дригало & 16,32 & $12,15 \%$ \\
\hline Легко! (Миронівський хлібопродукт) & 10,62 & $10,28 \%$ \\
\hline Еліка & 2,07 & $8,88 \%$ \\
\hline Добриня (Геркулес) & 11,4 & $8,88 \%$ \\
\hline Щедров (Ласка) & 3,63 & $5,61 \%$ \\
\hline Оса (ПП Урсуленко О.А.) & 3,63 & $5,14 \%$ \\
\hline Фарро (Кременчукм’ясо) & 1,55 & $4,21 \%$ \\
\hline Отаман (Три Ведмеді) & 1,55 & $4,21 \%$ \\
\hline Ласка & 2,59 & $3,74 \%$ \\
\hline Полісся & 3,37 & $3,74 \%$ \\
\hline Гармонія (Лубенський молочний завод) & 2,59 & $2,34 \%$ \\
\hline Київхліб & 3,89 & $3,27 \%$ \\
\hline Морозко & 4,15 & $3,27 \%$ \\
\hline Экономька (Левада) & 4,92 & $3,27 \%$ \\
\hline Цезарь & 1,55 & $3,27 \%$ \\
\hline Коло (ПП Урсуленко О.А.) & 1,55 & $2,8 \%$ \\
\hline Смачного (Царська охота) & 1,3 & $2,34 \%$ \\
\hline Богатир (Мушкетер) & 2,33 & $1,87 \%$ \\
\hline Добра вечеря & 3,11 & $1,87 \%$ \\
\hline Ванька-Встанька (Дригало) & 1,81 & $1,87 \%$ \\
\hline Маршалок & 1,32 & $1,4 \%$ \\
\hline Моя бабуля (Ласка) & 2,59 & $1,4 \%$ \\
\hline
\end{tabular}


Продовження табл. 1

\begin{tabular}{|l|c|c|}
\hline $\begin{array}{l}\text { Річний рейтинг за результатами голосування споживачів об- } \\
\text { числюється як середнє арифметичне балів, отриманих конкур- } \\
\text { сантом у кожному 3 4-ьох річних кварталів. }\end{array}$ & 2015 рік & $\begin{array}{c}2016 \text { рік } \\
\text { (за 3 квартали) }\end{array}$ \\
\hline Імператор смаку (Мушкетер) & 1,3 & $1,4 \%$ \\
\hline Велика ложка (Екотехніка) & 2,07 & $1,4 \%$ \\
\hline Архимагир (Архимагирь) & 1,3 & $0,93 \%$ \\
\hline Жарка Варка (Агропродинвест) & 0,53 & $0,47 \%$ \\
\hline Похитайло & 1,3 & $0,47 \%$ \\
\hline SтаСот & 2,07 & $0,47 \%$ \\
\hline Пекарь (Мушкетер) & 0,78 & $0,47 \%$ \\
\hline Лукавиця (Обухівський молокозавод) & 1,3 & $0,47 \%$ \\
\hline
\end{tabular}

Розглянемо докладніше діяльність виробників - лідерів ринку заморожених напівфабрикатів.

Компанія «Геркулес» є лідером в області виробництва заморожених напівфабрикатів. В Україні компанія працює вже 15 років. На виробничих потужностях використовується новітне обладнання, що дозволяе випускати продукцію високої якості. Крім того вся продукція компанії підлягає міжнародної сертифікації. При виробництві заморожених напівфабрикатів використовується сучасна технологія шокової заморозки, яка дозволяє зберегти всі корисні речовини і вітаміни готової продукції. Продукція підприємства «Геркулес» виробляється виключно з натуральної сировини, контроль якості якого проводиться в спеціальних лабораторіях підприємства.

Продукцію заморожених напівфабрикатів підприємство випускає під торговими марками «Геркулес», «Добриня», «Еники-беники», «Макарена», «Диканька».

Асортимент продукції включає: пельмені ТМ «Геркулес» фірмові, сибірські, курячі, з м'ясом індички, домашні; равіолі уральські і пельмені сімейні ТМ «Еники-беники»; равіолі сибірські і равіолі домашні ТМ «Добриня»; вареники ТМ «Геркулес»: 3 картоплею, 3 картоплею та грибами, 3 картоплею $\mathrm{i}$ печінкою, 3 сиром солодкі, 3 капустою, 3 вишнею;вареники з картоплею ТМ «Еники-беники»; тісто листкове і дріжджове ТМ «Геркулес».

Компанія «Геркулес» має 22 філії і 7 представництв на території України. Ексклюзивним дистриб'ютором $€$ ПП «Український продукт». Крім виробництва заморожених напівфабрикатів компанія займається виробництвом морозива і молочної продукції.

Компанія «Левада» - це один 3 найбільших виробників заморожених напівфабрикатів на ринку України. Компанія має відмінну виробничу базу, використовує новітні технології на виробництві, оновлює асортимент продукції.

Асортимент продукції ТМ «Левада»: пельмені 3 яловичиною та свининою, зі свининою, подомашньому, по-селянськи, по-козацьки зі шкварочками; млинчики з куркою і грибами, з сиром, ваніллю та родзинками, бендерики, налисники з вишнею; вареники 3 картоплею, з картоплею та грибами, з картоплею і печінкою, вареники «Улюблені» 3 тушкова- ною капустою, з солодким сиром, з картоплею та лісовими грибами, з картоплею та смаженою печінкою, 3 картоплею і смаженою цибулькою, серія продуктів «Ням-Ням» для діток, варенички з сиром, пельмені «Круглик», равіолькі соковиті, пельмені «Круглики» різнокольорові, равіолькі, тісто листкове і листкове дріжджове.

Компанія «Вічунай» випускає широкий асортимент продукції під торговою маркою «Vici» (Вiчi). Більшість продукції - це морепродукти, але під цією торговою маркою також випускаються готові страви 3 риби (рибні бургери, рибні палички, шматочки риби в паніровці), готові салати, картопля фрі, пельмені для смаження і піца.

ПП «Дригало»виготовляє заморожені напівфабрикати під кількома торговими марками. Так під ТМ «Дригало» виробляються пельмені, вареники, млинці, котлети, зрази, вироби з листового тіста, картопля фрі, тісто листове, тісто дріжджове, тісто пісочне та ін. Під ТМ «Ванька-Встанька» виробляються манти, котлети рибні, котлети курячі, млинчики, пельменькі; під ТМ «Ностальгія» - пиріжки, пельмені, котлети, підТМ «Немо» - готові рибні напівфабрикати (биточки, зрази, котлети, рибні палички, рибні бургери, риба в листовому тісті) під ТМ «Швідень-КО» можна знайти широкий асортимент готових обідів.

Миронівський м'ясопереробний завод «Легко» у своєму портфелі брендів має торгову марку заморожених напівфабрикатів «Легко». Завод використовує унікальну технологію замкнутого циклу, при якому повністю контролюється якість сировини та готової продукції: від вирощування кормів, переробки м'яса до виробництва готових виробів. Напівфабрикати ТМ «Легко» - це готові заморожені страви 3 м'яса птиці, свинини та яловичини власного заводу виробництва. Продукція випускається в трьох категоріях: вишукане меню (котлета по-київськи та котлета «Кордон Блю»), домашнє меню (котлета домашня, шніцель курячий і котлета 3 грибами та сиром) і снекменю (різні нагетси і курячий «попкорн»). Всі напівфабрикати ТМ «Легко» фасуються в пластикові лотки [7].

Висновки та перспективи подалыших досліджень. Проаналізувавши ринок заморожених напівфабрикатів можна зробити висновки, що:

- лідерами на ринку України є ТМ «Три ведмеді», «Геркулес», «Левада»; 
- основною проблемою, яка стоїть перед виробниками напівфабрикатів - це сировина. 3 кожним роком кількість сировини зменшується, а ціни на неї зростають;

- практично вдвічі в порівнянні з минулим роком збільшилися ціни на базову сировину (м'ясо, сало, борошно) та інгредієнти для виробництва напівфабрикатів.

Виходячи саме $з$ цих проблем підприємствавиробники змушенні підіймати ціни на готову продукцію.

На розвиток так званої «напівфабрикатної» галузі впливають також такі чинники: низька якість української сої;висока вартість закордонного обладнання;відсутність сучасного українського устатку- вання для виробництва заморожених напівфабрикатів;труднощі входу в мережі супермаркетів.

Хороші можливості сьогодні мають виробники, які виготовляють традиційні продукти в середньому ціновому сегменті, тому що на них прогнозується підвищення попиту. Можливі також скорочення витрат виробників на виведення і просування нових марок та зниження рівня конкуренції в середньому і високому цінових сегментах. Резюмуючи, хочу відзначити, що навіть в умовах кризи ринок заморожених продуктів збереже свою привабливість і буде рости, але не такими високими темпами. Разом з тим аналітики прогнозують досить високі темпи розвитку сегмента напівфабрикатів 3 м'яса птиці.

\title{
Література
}

1.Козій С.О. Перспективи розвитку ринку напівфабрикатів [Електронний ресурс] / С.О. Козій. Режим доступу: https://nubip.edu.ua/sites/default/.../zbirnik_konferenciyi_11_05_2017.pdf

2.Номенклатура продукції промисловості. - Державна служба статистики України. - К., 2013. - 543 с.

3.Статистичний щорічник України за 2013p. / За ред. О.Г.Осауленка. - Державна служба статистики України. - К.,2014. - 527 с.

4.Товарознавство продовольчих товарів: [підруч.] / За ред. І.В. Сирахмана. - К., 2000. - С.262, 308.

5. Шубина Г. Рынок замороженнях полуфабрикатов: общая ситуация / Г. Шубина // Продукты\&Ингредиенты. - 2012. - №3 (89). - С.38-40.

6. Шугурова Т. Инновационныйподход к производству натуральних полуфабрикатов / Т. Шугурова // Мяснойбизнес. - 2011. - №4. - С.56-57.

7. Брендингове агентство Koloro [Електронний ресурс]. Режим доступу: http://koloro.ua/company.html

8. Портал для споживачів FAVOR [Електронний ресурс]. Режим доступу: https://www.favor.com.ua/vote/products/frozen-convenience-food/?results=U.

\author{
Свистун Т. В. \\ кандидат экономических наук, доцент \\ E-mail: tatyana dud@mail.ru \\ Туз E.B. \\ магистрант \\ кафедра управления бизнесом \\ Одесская национальная академия пищевых технологий \\ ул. Канатная, 112, г. Одесса, Украина, 65039 \\ E-mail: Katia-tuz@yandex.ru
}

\section{АНАЛИЗ РЫНКА ЗАМОРОЖЕННЫХ ПОЛУФАБРИКАТОВ УКРАИНЫ}

В статье рассмотрены основные тенденции потребления и ассортимент замороженных полуфабрикатов Украины. При проведении анализа были определены: лидеры рынка Украины, основные проблемы производителей, факторы, влияющие на развитие.

Современные тенденции в питании населения все больше ориентированы на развитие рынка быстрых и легких в приготовлении продуктов, которые одновременно имеют высокую пищевую ценность и доступны для рядового потребителя. В современном ритме жизни полуфабрикат - это очень популярный продукт среди домохозяек в силу того, что готовится он довольно быстро и легко. Подобные продукты почти готовы. Чаще всего их даже не нужно размораживать перед тем, как готовить. 
Самая популярная категория полуфабрикатов в Украине - мясные полуфабрикаты (с использованием теста и без него). Вместе с пельменями их доля составляет более $80 \%$ от всего потребления замороженных полуфабрикатов. Среди мясных полуфабрикатов можно выделить рубленые полуфабрикаты (фарш, различные котлеты, биточки, зразы, фрикадельки). Наблюдается рост спроса на мясные полуфабрикаты из птицы. поскольку данная продукция считается более диетической. В Европе же наиболее популярным полуфабрикатов является пицца.

Ключевые слова: заморозка, полуфабрикаты, лидеры рынка, основные производители, развитие отрасли, основные проблемы.

\author{
Svystun T. \\ Ph.D., Associate Professor \\ E-mail: tatyana dud@mail.ru \\ Tuz K. \\ Undergraduate \\ Department of Management of Business \\ Odessa National Academy of Food Technologies \\ Kanatna str., 112, Odesa, Ukraine, 65039 \\ E-mail: Katia-tuz@yandex.ru
}

\title{
MARKET ANALYSIS OF SEMI-FROZEN OF UKRAINE
}

The article describes the basic trends of consumption and range of frozen semi-finished products in Ukraine. In the analysis the leaders of the Ukrainian market, the main problems of the producers, the factors influencing the development, have been identified.

Current trends in the nutrition of the population ave increasingly focused on the market development of quick and easy preparing of foods that also have high nutritional value and accessible to the ordinary rhythm of modern life consumer. In modern life a semi-finished product - a very popular product among housewives due to the fact that it is prepared quickly and easily enough. These products are almost ready. Often they do not even need to defrosted before cooking.

The most popular category of semi-finished products in Ukraine - meat preparations (using dough or without it). Together with dumplings, their share is over $80 \%$ of the total consumption of frozen food. Among meat products chopped meal (minced meat, various burgers, meatballs) can be identified. There is a growing demand for meat products from poultry. because this product is considered a dietary one in Europe, the most popular is semi pizza.

Keywords: frost, semi-finished products, the market leaders, major producers, development of the industry, the main problems.

\section{References}

1. Kozii, S. O. "Perspektyvy rozvytku rynku napivfabrykativ." Https://nubip.edu.ua/sites/default/.. ./zbirnik_konferenciyi_1_03_2017.pdf. N.p., n.d. Web. 1 March 2017.

2. Nomenklatura produktsii promyslovosti. - Derzhavna sluzhba statystyky Ukrainy. (2013). K.

3. Osaulenka, O. H. (2014). Statystychnyi shchorichnyk Ukrainy za 2013r. K.: Derzhavna sluzhba statystyky Ukrainy.

4. Syrakhmana, I. V. (2000). Tovaroznavstvo prodovolchykh tovariv. K.

5. Shubyna, H. (2012). Rыnok zamorozhenniakh polufabrykatov: obshchaia sytuatsyia. Produktы\&Ynhredyentы, 3(89), 38-40.

6. Shuhurova, T. (2011). Ynnovatsyonnuipodkhod k proyzvodstvu naturalnykh polufabrykatov. Miasnoibyznes, 4, 56-57.

7. Brendynhove ahentstvo Koloro. Retrieved March 1, 2017, from http://koloro.ua/company.html

8. Portal dlia spozhyvachiv FAVOR. (n.d.). Retrieved March 1, 2017, from https://www.favor.com.ua/vote/products/frozen-convenience-food/?results=U. 